\title{
The Foreign in the Familiar, or The Other in the Own. Africa and Images of the Other in the Dresden State Art Collection
}

\author{
Silvia Dolz \\ Museum für Völkerkunde Dresden \\ Silvia.Dolz@skd.museum
}

\begin{abstract}
Many European museums hold unusual, «hybrid» objects from various periods and areas of the world that reflect images of the Other. The collections of both European and non-Western art belonging to the Staatliche Kunstsammlungen Dresden, Germany, include very early evidence of perception of the Other going back as far as the $16^{\text {th }}$ century. Using a number of examples from Dresden ranging in date from this early period down to the $20^{\text {th }}$ century, and by adopting a different vantage point and hence a change in perspective, this paper attempts to consider and re-evaluate social and cultural foreignness and Otherness and to elucidate its ambivalent and ambiguous relationship with the Own and the Self. The multiple layers of meaning inherent in the museum-held cultural objects which are influenced by or related to the "foreign", or have a hybrid appearance, can, when viewed from a different historical and locational perspective, contribute to our understanding of intracultural and also intercultural distance and connection, identities and intentions, realities and constructions, and thus provide a better understanding of transcultural processes.
\end{abstract}

KEYWORDS: Global Art History; Multiperspectivity; Otherness; Cultural Hybridisation; Transculturation; Staatliche Kunstsammlungen Dresden.

\section{Lo extraño en lo familiar o lo otro en lo propio. África y las imágenes del otro en la colección estatal de arte de Dresde}

RESUMEN: Muchos museos europeos tienen objetos poco corrientes, híbridos, que, procedentes de distintos periodos y áreas del mundo, son un reflejo de la imagen del Otro. Las colecciones, tanto de arte europeo como no occidental, pertenecientes al Staatliche Kunstsammlungen de Dresde, Alemania, incluyen testimonios muy tempranos de la percepción del Otro, que se remontan hasta el siglo XVI. A través de una serie de ejemplos de Dresde cuya cronología se extiende desde esas fechas tempranas hasta el siglo XX, y por medio de la adopción de un punto de vista diferente y, por ende, de un cambio de perspectiva, este artículo intenta considerar y reevaluar la extranjería y la Otredad sociales y culturales con el fin de elucidar sus ambiguas y ambivalentes relaciones con lo Propio y el Yo. Las múltiples capas de signiticado inherente en la colección de objetos culturales influidos o relacionados con lo «extranjero», o que tienen una apariencia híbrida, pueden, cuando se perciben desde una perspectiva histórica y geográficamente diferente, contribuir a nuestra comprensión intra e intercultural de la distancia y las conexiones, las identidades y las intenciones, las realidades y las construcciones, y, de este modo, procurar una mejor comprensión de los procesos transculturales.

PALABRAS CLAVE: Historia del arte global; Perspectivas múltiples; Otredad; Hibridación cultural; Transculturación; Staatliche Kunstsammlungen Dresden.

In the current context of reorientation and the re-evaluation of objects and collections held in cultural and art historical museums, there is nowadays much talk of global integration, transcultural processes, uniform phenomena and reactive cultural diversity. Particularly with regard to the contents of ethnological museums, present-day discourses on multiperspectivity and the multiple layers of meaning in objects touch on topics that direct attention towards global society, including one's own cultural community, and focus on the desirable and necessary dialogue between different cultures. Many of the artis-

Cómo citar este artículo: DOLZ, Silvia, «The Foreign in the Familiar, or The Other in the Own. Africa and Images of the Other in the Dresden State Art Collection", Boletín de Arte-UMA, n. 38, Departamento de Historia del Arte, Universidad de Málaga, 2017, pp. 21-34, ISSN: 0211-8483, DOI: http://dx.doi.org/10.24310/BoLArte.2017.v0i38.3287 
tic objects preserved in museum collections, some of which were long marginalised and have only recently come back into view, raise important questions in this connection: In cross-cultural interaction, how does the familiar (the «Own») relate to the foreign (the "Other»), and vice versa? What is the "Own» in the "Other», or the "Other» in the "Own», and in either case what does it mean? What does it essentially say about our perception of ourselves and others, and about power relations, i.e. about the intentions behind interaction between the familiar and the foreign? These questions engender a number of different effects and dependencies, and can be answered from different perspectives. The terms "Other» and «Own» turn out to be ambivalent and ambiguous: for example, with a change of location or vantage point, the «Own» in the «Other» seems like something «Other» in a different "Own». From this new basis it is evident that the Other is manifested in the Own, and that in so doing it can be transformed into an Other that is distinct from the Self. What is certain is that, in all these interactions, both the Other and the Own undergo change. Alongside this external perspective, an internal viewpoint is always involved at the same time: the Other as the subconscious and unfamiliar within one's own Self, e.g. as part of one's own personality. Does so much ambiguity really exist in the lived world? Indeed it does, if the different relationship systems, knowledge traditions and complex interrelations are taken into account This article will treat this topic using a complex approach, incorporating constant changes of perspective with regard to cultural interaction, a process that will be examined with reference to Europe and Africa - two continents with a history of contact going back at least 500 years.

The hermeneutic questions posed in the introduction are not unimportant for understanding this complex subject. They are intended to show how the Own and the Other are interdependent, only coming into being, in fact, through contact with one another. Certain categories of objects in modern art and ethnographical museums demonstrate how universal the phenomenon of constructing the Own and the Other is. Nevertheless, the values attached to those objects change over time, in the same way as the image of the Other and the perception of the Own also alter over the course of history. Thus, through such objects it may be possible to trace and comprehend processes of cultural change and cultural hybridisation. However, they also play a role in cre- ating awareness, as well as in shaping images of the Other and forming stereotypes. Taking a few outstanding objects dating from various periods and from different cultural contexts as examples, it is possible to demonstrate that those objects are essentially contemporary symbols, objectified expressions of a worldview and their creators' perception of their own identity.

Let us first consider the European perspective. A perception of the Other which we would today regard as being global in extent began to be manifested primarily in the early "Kunst- und Wunderkammern» (chambers of art and curiosities) of the Renaissance and Baroque periods. In 1560, at approximately the same time as important collections of this kind were being established at Schloss Ambras near Innsbruck, in Prague, Vienna and Munich, a Kunstkammer was instituted in Dresden by Elector August of Saxony (15261586). This assemblage of curiosities soon also contained exotic products of human creativity. By presenting naturalia, scientifica and artificialia, the Kunstkammer was intended as a microcosm, a small-scale reproduction of the universe, knowledge of which was increasing owing to the European discovery and conquest of the world and the development of modern science (Syndram, 2004: 8-9). From the $16^{\text {th }}$ to the $18^{\text {th }}$ century, fascinating objects from distant parts of the world were collected in the Dresden Kunstkammer for the purpose of awakening curiosity and inquisitiveness, but above all in order to evoke astonishment and admiration. A remarkable collection of ivory objects, later identified as Afro-Portuguese ivories, as well as West and Central African ceremonial weapons, were already included in the Dresden treasure collections as early as $1590^{1}$. The unusual objects collected in early princely collections reflect a fascination with the exotic and an open attitude to the world at large, but also a desire for ostentatious displays of power and prestige. They included engravings and paintings, weapons, precious textiles and valuable accessories, along with sculptures. Particularly impressive are an early figural automaton featuring «Africans» ${ }^{2}$ and a collection of small statuettes depicting "Moors", most of which were created in Dresden between 1690 and 1725. These were displayed in the collection of treasury objects, the Grünes Gewölbe (Green Vault). They were not the first representations of black people in Europe. In Christian art, black figures were not unusual in depictions of the Magi, St. Mauritius or the baptism of the «Ethiopian» (Ke- 


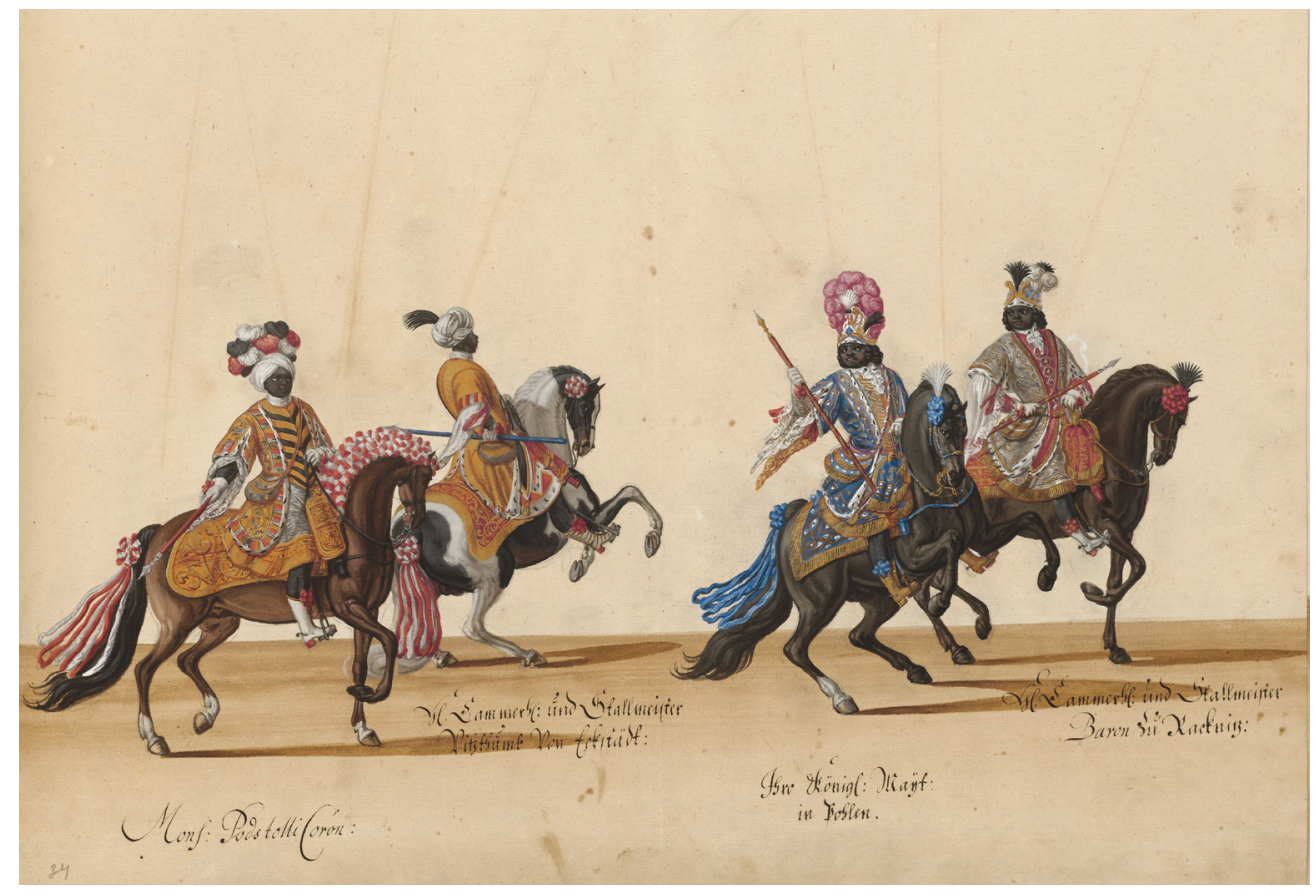

1. Johann Mock, August the Strong and courtiers as contestants in the "Moors' Quadrille» in Warsaw on 5 February 1701, 1706, watercolour and opaque paints, 39.4 x 55 cm, Staatliche Kunstsammlungen Dresden, Kupferstich-Kabinett, Inv. no. Ca 193, sheet 32. Photo: Herbert Boswank

telsen, 2006: 60-64). In Early Modern allegories there were also personifications of the continent of Africa, represented in engravings in the form of beautiful dark-skinned «Ethiopian» women (Ketelsen, 2006: 64-73). The statuettes of «Moors» in the Grünes Gewölbe are related to something else, however. As personal and particularly cherished cabinet pieces belonging to the Elector, they were created as extravagant and luxurious objects reffering to the spectacular festivities staged by the prince, such as elaborate masked processions or pageants, musical and ballet performances or as decorations for banquets at the Saxon court (Von Bloh, 2006: 76, 82). The desire to participate in the discovery and exploration of the world in the $16^{\text {th }}$ and $17^{\text {th }}$ century opened the door to all sorts of fantasies. The staging of theatrical triumphal processions with representations of the virtues, the four elements, the planets and constellations, the continents and various peoples, were intended to portray the world (Greve, 2006: 20). Particularly in the case of August the Strong (1670-1733), Elector of Saxony from 1694 and King August II of Poland from 1697, who had residences in both Dresden and Warsaw, the exotic courtly festivities, which also involved Africans designated as «Moors", served essential political purposes as ostentatious demonstrations of princely power and esteem. The Elector himself was the supreme «arranger» of the event, played a central role as the «King of the Moors» and had these choreographed performances meticulously documented in magnificent paintings and engravings ${ }^{3}$ [1]. It is conceivable that it was precisely these documentary images produced at the Saxon court that were the inspiration behind many of the «Moor statuettes». Since the second half of the $16^{\text {th }}$ century, there had periodically been Africans at the Saxon court, mostly in the role of higher-ranking servants, where they were intended to demonstrate a kind of interconnectedness of the world, yet these people do not seem to have been the models for the depictions of «Moors». The Dresden-based sculptor Balthasar Permoser (1651-1732), the court goldsmith Johann Melchior Dinglinger (1664-1731) and the court jeweller Johann Heinrich Köhler (1669-1736) created a large number of «Moors" as expressions of exclusive sensual beauty thoroughly in keeping with European 


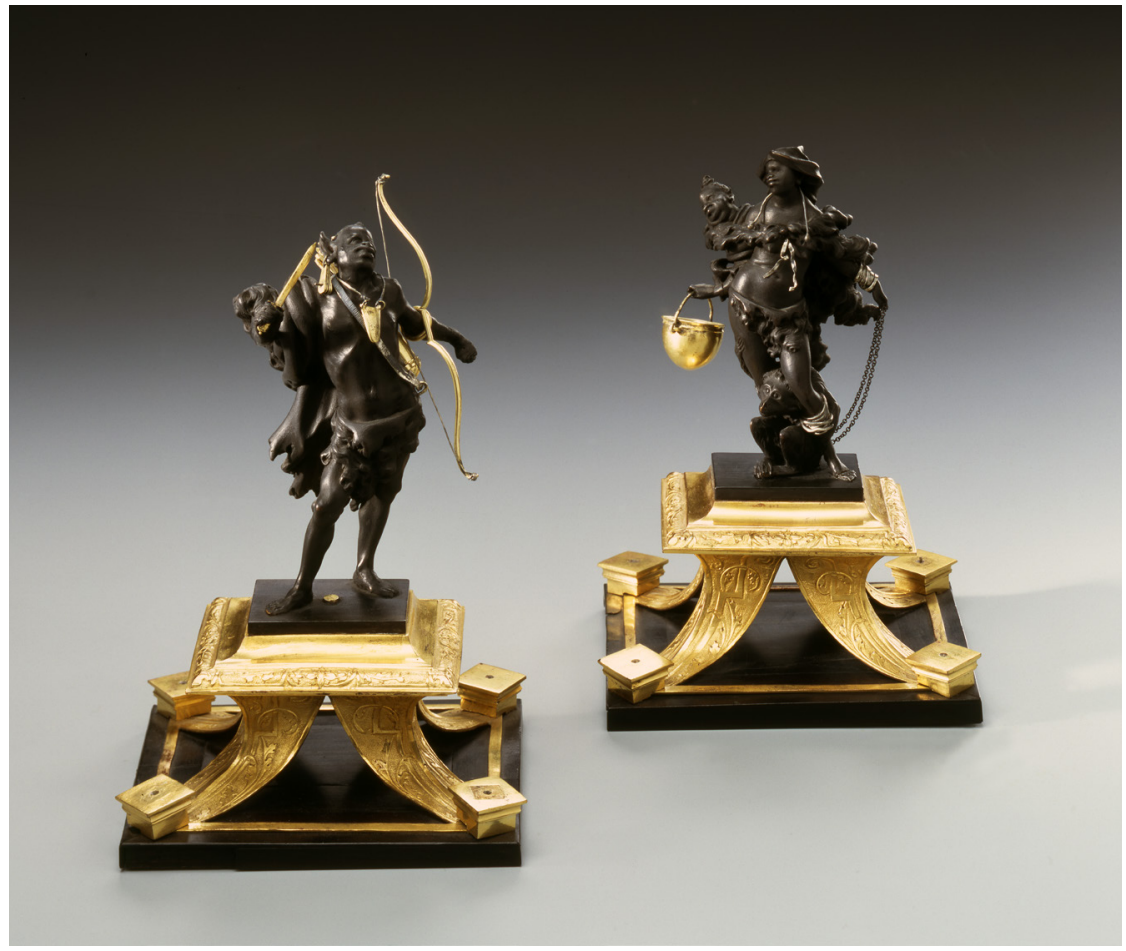

2. Statuettes depicting a Hottentot couple, ebony, wood, silver gilt, Balthasar Permoser, Dresden, 1705, H 12.1 and $12.6 \mathrm{~cm}$ (without plinths), Staatliche Kunstsammlungen Dresden, Grünes Gewölbe, Inv. no. VI 237, VI 238. Photo: Jürgen Karpinski pictorial tradition. Outstanding examples are the statuettes of a «Hottentot couple», created in Dresden by Permoser in 1705 (Syndram, 1999: 80) [2]. Although these carved ebony figures are recognisable as foreign on account of their clothing and physiognomy, they nevertheless correspond to the classical ideal known from antique sculpture, and so they emanate a familiar aura of loftiness. The sculpture of a black drummer on horseback, made of ebony and ivory, which was produced between 1695 and 1700, depicts an African wearing decorative feathers, an imaginative counterpart to the representations of "American Indians" dating from the same period ${ }^{4}$ [3]. Probably the most imposing figure depicting a «Moor» in Dresden is the «Moor holding Emerald Ore» produced in 1724 [4]. Both the choreography of the festivities and the design of the sculptures were probably based on engravings made to illustrate the famous travel accounts published during this period. These include the editions of «India Occidentalis» (published as a series of volumes starting in 1590) and «India Orientalis» (published from 1597) produced by the workshop of De Bry, which showed people both from America and from the «Congo» wearing feather headdresses and standing in classical poses, but which also include the "Description of Africa" produced by Olfert Dapper in 1671 and even the work by Peter Kolb about the Cape of Good Hope and its inhabitants, the «Hottentots», which was not published until $1719^{5}$.

In their exotic appearance, mostly naked and wearing extravagant ornamentation, the Baroque «Moor figures» do not convey an image consistent with the real world ${ }^{6}$. Rather, the black Other is perceived with ambivalent fascination; his nakedness indicates a character who is not corrupted by civilisation and is close to nature, living in a world shrouded in legend ${ }^{7}$. At the beginning of the Enlightenment period, when the exploration of the continents was just beginning, the masquerades and courtly festivities with specific reference to the Other, which included not only Africa but also America and the Orient in the broadest sense, presented a field for experimentation in which voyeuristic exoticism was combined with a spirit of enquiry and a desire for theatrical entertainment. People were both attracted to and repelled by that which was foreign and different. The dark skin was seen as a symbol of an impure, black soul which, unlike the 


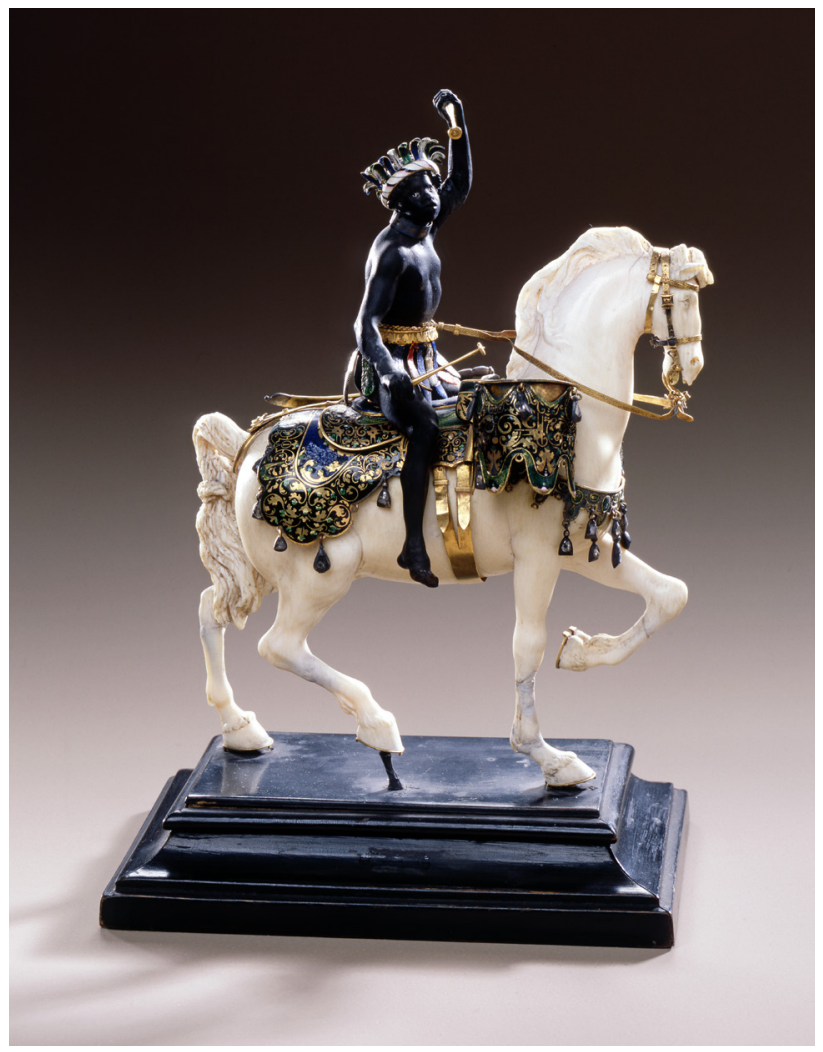

3. African drummer on horseback, wood, ivory, gold, enamel, precious stones, Balthasar Permoser and Johann Melchior Dinglinger, Dresden, 1695-1700, H 17.2 cm, Staatliche Kunstsammlungen Dresden, Grünes Gewölbe, Inv. no. VI 193. Photo: Jürgen Karpinski

skin, could be cleansed through Christianity and baptism, i.e. it could be «whitewashed»8. There were two ambivalent tendencies: on the one hand, there was fear of the Other, of the unfamiliar and uncontrollable, against which it was necessary to defend oneself; on the other hand, there was a desire to investigate the Other, to gain knowledge about it and to integrate it into a familiar system of categorisation and evaluation. Thus, meaning was imparted to the Other, lending it a certain justification. This is an intellectual, social, psychological and emotional strategy for dealing with unfamiliar things that are perceived as a threat. Despite clearly segregating themselves from the Other, Europeans incorporated its exclusivity, adopted it as their own, and thus established their own social and societal identity. The Other was thus no longer alien but became a different Self. When August the Strong assumed the role of «King of the Moors", he not

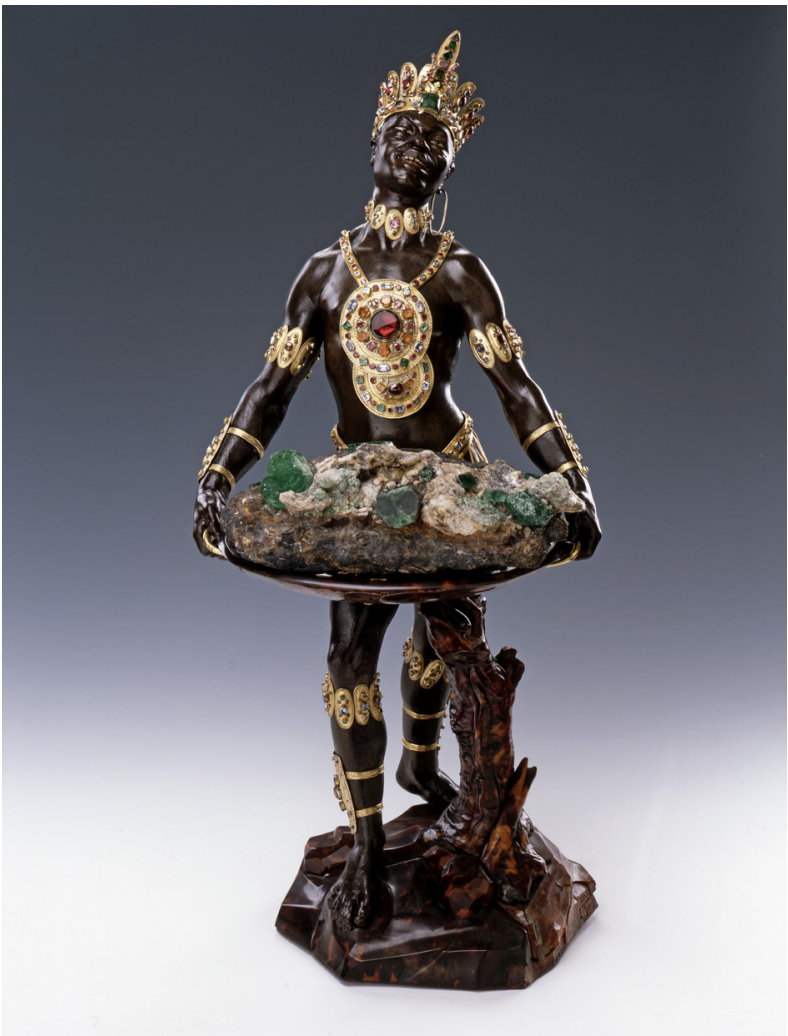

4. Moor holding emerald ore, wood, silver gilt, tortoiseshell and precious stones, Balthasar Permoser and Dinglinger workshop, Dresden, 1724, H $63.8 \mathrm{~cm}$, Staatliche Kunstsammlungen Dresden, Grünes Gewölbe, Inv. no. VIII 303. Photo: Jürgen Karpinski

only visually demonstrated his special status but by combining the Own and the Other he elevated his identity and expressed his aspiration to become the ruler of the world by simultaneously representing two kings (Greve, 2006: 20).

The «Moor statuettes» could also be regarded in a similar way. The Other served primarily to underline the exclusive prominence of the ruler and to celebrate the role of the princely court. The drummer on horseback was part of a procession befitting a high-ranking prince; the number and lavishness of such processions being a prestigious instrument of power (Syndram, 1999: 65). This figure is a symbol of military glory, as are also two «Moorish archers» from the Grünes Gewölbe (Greve, 2006: 82-83). The desire to share in the immeasurable wealth of the world is demonstrated by the ornate figure of the "Moor» holding emerald ore. This and the «Hotentott figures», as emissaries of a distant conti- 
nent, may reflect the «dream of Sun-Kingship» (Greve, 2006: 83). Hence, through the staging of entertainments featuring the exotic Other, the rulers revealed their own ideas about the world and manifested their own yearnings, while at the same time these ostentatious festivities satisfied their desire to demonstrate their prestige and claim to power before the eyes of their European rivals. However, aspirations of gaining power over foreign territories - an objective which was already becoming apparent during this early period of European exploration of the world - were destined, two centuries later, to bring about major changes in the Own, turning it into an Other that turned ideas about the exotic Other and stereotypical images into notions of an enemy or bogeyman.

Exotic curiosity was still evoked by foreign objects during the modern period in Europe. In the late $19^{\text {th }}$ and early $20^{\text {th }}$ century, the last territories on earth were opened to commercial exploitation by European colonial powers in a way that evoked a great deal of sensational publicity. In parallel to this, ideas of Otherness were reflected in the process of amassing encyclopaedic knowledge in an effort to prove evolutionary models of human development. Unfortunately, however, this also led to the formulation of justifications for the moral, political and economic supremacy of Europe over the Other. For a long time to come, ideas of exoticism and primitivism, as well as a colonial system that pervaded all aspects of life, were to shape the relationship of the Own to the Other from a European perspective. «Human zoos» (or «ethnological expositions») and major international exhibitions in many European capitals, which led to the marketing of «colonial products» by means of advertisements featuring stereotypical images of the Other, served to familiarise the general public with the Other in order to prepare its appropriation into the Own'. However, apart from being an object of exotic curiosity and an instrument for promoting colonial power interests, the Other also began to develop into a mediator, and sometimes into the essence, of an alternative, idealised way of life, in which people sought a return to nature, or to the simple and primordial. In 1905 four young architecture students met in Dresden and formed a group centring on the figure of Ernst Ludwig Kirchner (1889-1938). Together they established the Expressionist artists' group BRÜCKE (meaning «bridge»). In the context of an intellectual and socially critical process that was underway in early $20^{\text {th }}$-century Germany and Europe, the BRÜCKE artists sought inspiration from the completely different stylistic vocabulary in works of art from Oceania and Africa, bringing about a change of perspective and a paradigm shift in the European academic art tradition ${ }^{10}$. Particularly in the case of Ernst Ludwig Kirchner, Erich Heckel and Karl Schmidt-Rottluff, their first encounter with the Other took place in the Museum für Völkerkunde (Ethnographic Museum) in Dresden ${ }^{11}$. They felt this encounter to be a positive experience of non-Western cultures, which although allegedly «primitive» were, as they saw it, authentic. On the basis of these experiences, they proceeded to construct an ideal counter-world, which they simulated in their studios ${ }^{12}$. The BRÜCKE artists had little opportunity to explore the world of the Other beyond its vocabulary of forms, since academic research into that world was only just beginning at that time. Their efforts to bring the Own into an equal relationship with the Other was based primarily on the desire to overcome their own traditional concepts of art. A new identity in the art of the $20^{\text {th }}$ century developed out of interaction with the Other, but mainly in the form of an initially uncritical and syncretistic appropriation of foreign styles, out of which they expected something new and different to evolve. In his Davos diary of 1925, Kirchner reflected on the fact that in the Ethnographic Museum in Dresden he had discovered parallels with his own aims, but that he had also realised that his own form had to be something different: «Only the manner of translating observation into form was the same, never the result or the objective ${ }^{13}$.» This new Other, however, seemed to be beyond any self-doubt.

Among the many African works of art in the Ethnographic Museum in Dresden, the BRÜCKE artists selected motifs in which they recognised simple and eye-catching designs, often with unrealistic proportions. It is conspicuous that they were attracted primarily by things that were somehow familiar to them from the European art tradition. Kirchner was fascinated by the sculptures from the historic Benin Empire in Nigeria, particularly the bronze plaques with narrative reliefs. Several drawings by Kirchner after studies of objects in the Dresden Ethnographic Museum have now been identified. In these practice sketches he attempted to swiftly capture what he considered to be the essence of the respective object and to express it in a new stylistic idiom. On the one hand, the (for him) unknown meaning signified by the foreign object encouraged a reduced and abstract response to it; on the other hand, the ambiguity of the foreign work of art 
helped him to find new interpretations from within his own realm of experience and knowledge. In just a few sketched lines he intuitively recorded what he considered to be the most important elements of a bronze plaque in the Dresden collection that measures $43 \times 40 \mathrm{~cm}$ and includes numerous figures and intricate details [5], thus indicating that his intended purpose was not mere imitation [6]. What particularly interested Kirchner about this bronze plaque from the Benin Empire in West Africa was the solution to a design problem: the absence of perspective. The «African» solution was to create an arrangement in which the various persons shown on the two-dimensional surface were depicted in different sizes. The artists from Benin had not aimed to reproduce a real situation. Although Kirchner knew nothing about the history and significance of the figures on the plaque, he sensed that the large person in the middle was the most important and the small figures positioned away from the centre must be of lesser significance. At first glance, his drawing appears to be an imitation of the original, but it reveals how differently things that are not immediately obvious can be translated into a simple vocabulary of forms. This also includes misinterpretations and open questions, however, as can be seen in a tiny detail in Kirchner's drawing: among the many details on the plaque, he has emphasised the cross on the chest of one of the companion figures, this being a symbol that was familiar to him. The gesticulating person that is visible only upon closer inspection, as well as an ornament in the background, are likewise emphasised and given an equivalent status to the other motifs. It is clear that these signs and images are mysterious to him and he is unable to decode them.

In fact, every detail of the relief plaque is of significance within the cultural context of the Benin Empire, where they functioned as instructions and reminders for choreographing court rituals. The images on the plaque depict a ceremonial scene, probably the Igue festival at the Royal Court of Benin, which prepared the King - represented in the centre as the largest figure - for coming into contact with the transcendental world in order to ensure that spiritual power was transferred to him. He is marked out as the powerful ruler not by insignia, as is usual; instead, his elaborate coat, collar, leg cuffs and chest band with coral beads demonstrate his role as king of the Benin Empire. The absence of styled hair and headgear shows him to be in a state of transition. It is only the widespread African perspective of social significance that

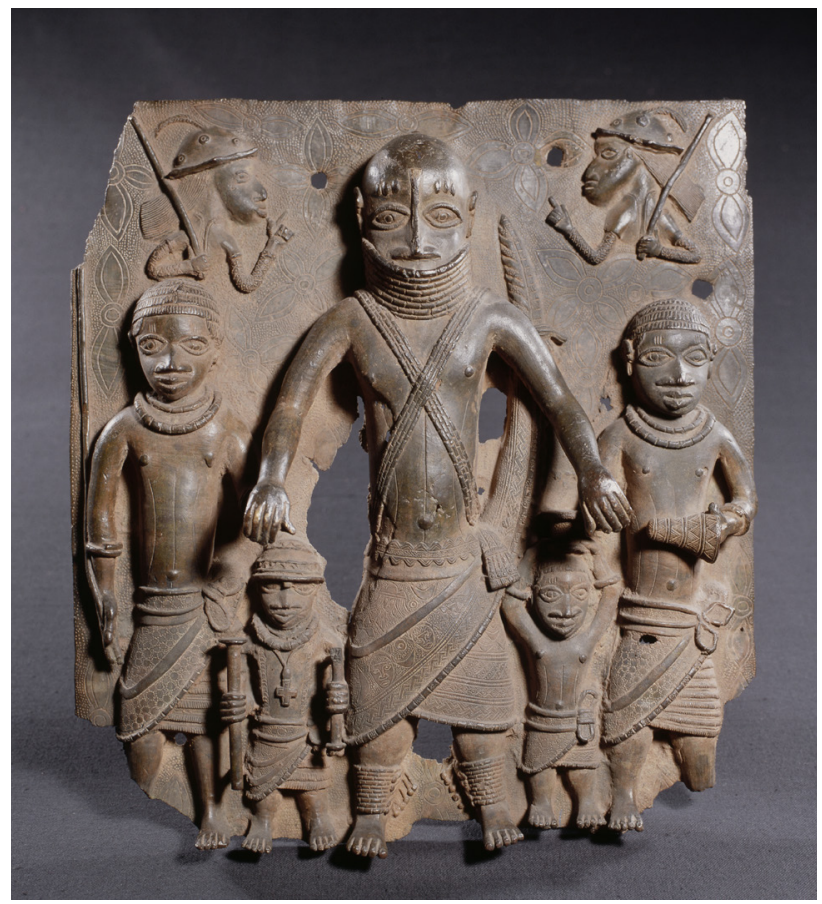

5. Relief plaque depicting an Oba with retinue, Brass, Benin Empire, Nigeria, $16^{\text {th }}-18^{\text {th }}$ cent., H $43 \mathrm{~cm}$, W $40 \mathrm{~cm}$, A. Baessler collection 1899, Staatliche Kunstsammlungen Dresden, Museum für Völkerkunde Dresden, Inv. no. 16 139. Photo: Eva Winkler

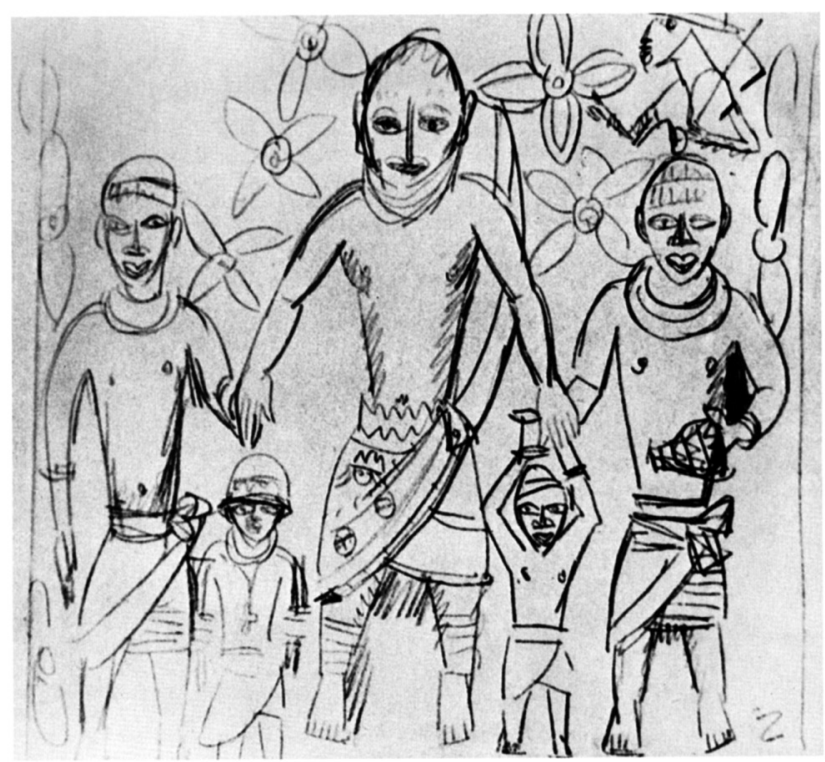

6. Ernst Ludwig Kirchner, Drawing after a Benin Bronze, pencil, 1911, according to the Ernst Ludwig Kirchner Archive, Wichtrach/Berne, its whereabouts is unknown 
shows the imaginary status and rank of individual persons as well as certain elements. The frequently oversized depiction of the head or other parts of the body has nothing to do with a "primitive ineptitude» in artistic representation, but is instead used to deliberately emphasise something of mythical, religious or societal significance. The gesticulating persons in the background represent Portuguese figures who are intended to reinforce the significance of the scene as a whole (see also the final section below), but who remain marginal figures. The cross - from a European perspective, a symbol of Christianity - and the quatrefoil ornament are regarded in the culture of Benin as references to a universal understanding of the world which is integrated into a mythical and religious/spiritual constellation.

The Other that was appropriated in Europe at that time - i.e. those foreign elements which had become more or less familiar through artistic adaptation or through being encountered in everyday life or being explored - was, on the one hand, wistfully idealised and yet, on the other hand, was kept at a distance by means of sociocultural and increasingly racist prejudice. In addition, the same purpose was served by the collections of objects from all aspects of life in the ethnographic museums, which were intended to illustrate and justify cultural diversity and difference in the process of determining lower and higher levels of culture-historical development. On the basis of these collections, numerous scientific dependence theories were developed, which until well into the $20^{\text {th }}$ century had the effect of clearly distinguishing the Other from the Own. Thus, the Other reflected not only the young avant-garde artists' own expectations. Despite their rebellious methods directed against their own culture, which they perceived as alien to them, they were nevertheless fundamentally rooted in the European zeitgeist. The inspiring Other, which comes to light in the Own of the BRÜCKE artists, turns out to be a cultural construct within a Eurocentric worldview which was to become increasingly nationalistic during the $20^{\text {th }}$ century.

Insights into the history of European culture and art as illustrated by the collections preserved in Dresden reveals a multifaceted relationship between the Other and the Own, which is also asymmetrical. The absorbed Other as something unknown, undefined and uncontrollable has been translated into something different which, although it is now familiar, one nevertheless seeks to distinguish from the Own.
In this context, it seems to be immaterial whether the Other has a positive or negative connotation. The Own is always defined through the Other, and in this interrelationship a process of creating something decidedly "other» is always set in motion (Reuter, 2002: 146). However, there is always something in-between, ambiguous phenomena that are manifested in culturally hybrid objects. Ambiguity is usually expressed through language, both in interpersonal and in intercultural encounters in diplomacy, satire, the avoidance of taboos and in resistance (Groschwitz, 2017: 143). Ambiguity is also used in coded form in signs and objects as a means of social and intercultural communication. How and why this happens depends largely on an imbalance of power between the Own and the Other. A shift to the «African» perspective will make this clearer.

Since at least $1684^{14}$ a unique object has been held in Dresden, where it was initially recorded in the inventory of the so-called Indianische Cammer ([American] Indian Chamber) at the court of the Electors of Saxony. Measuring almost one metre in length, it is an ivory signal horn decorated with the figure of a European [7]. This signal horn, which is now attributed to the Sapi-Portuguese tradition of ivory carving, is not comparable with the "olifants» which were produced by African craftsmen on the western part of the Guinea coast on behalf of Portuguese clients between 1490 and 1530. Unlike such olifants, which were modelled on European hunting horns and had a mouthpiece, this signal horn is a side-blown trumpet, an instrument that was widespread in Western and Central Africa (Bassani, 2005: 238-249). In place of a mouthpiece, the narrow end is decorated with a figure that, in African terms, is foreign-looking, whose naturalistic design - a man with individual facial features (a furrowed forehead, distinctive nose, and a beard) as well as a cylindrical hat - is worked in accordance with the rules of African iconography [8]. The Europid physiognomy is subordinate to an early form of design found among the Baga, Temne and Bullom ethnic groups on the coast between modern-day Guinea and Liberia, which is characterised by a squatting posture with the hands positioned under the chin and by another important stylistic element, the form of the eyes. These ethnic groups, whom Portuguese seafarers designated Sapi, or possibly even their ancestors, produced soapstone sculptures in the same posture, the function of which has not yet been clearly identified. It can probably be assumed that they represented 

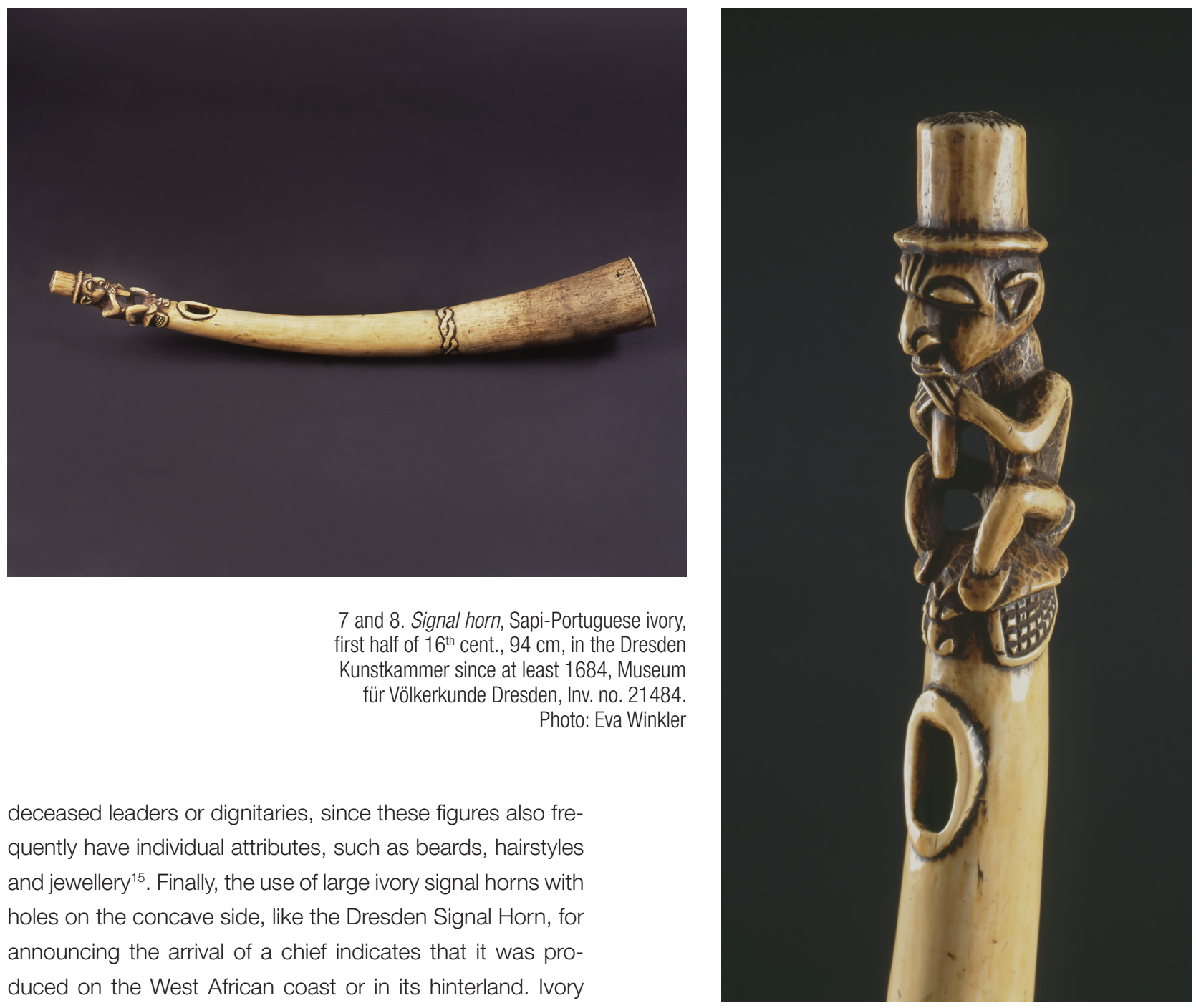

deceased leaders or dignitaries, since these figures also frequently have individual attributes, such as beards, hairstyles and jewellery ${ }^{15}$. Finally, the use of large ivory signal horns with holes on the concave side, like the Dresden Signal Horn, for announcing the arrival of a chief indicates that it was produced on the West African coast or in its hinterland. Ivory was regarded as a noble material reserved for the privileged elites. The rare occurrence of the figure's almost individual physiognomy and its particularly early arrival in Europe would seem to indicate that, like other Afro-Portuguese works of art, this item was specially commissioned. However, the signal horn differs from the known Sapi- and Bini-Portuguese salt cellars, pyxides, hunting horns and decorative spoons ${ }^{16}$, which were produced only for foreign customers and were not used in an African cultural context. The signal horn with the figure not only corresponds to local design ideas, including its decoration with spiral bands, a motif common in West Africa; rather, the image of a formidable-looking European seems to give an impression of approachability and authority as well as representing the privileges and power of an African ruler. For it was the local chiefs who monopolised and

benefited from trade with Europeans. As far as is currently known, the Dresden signal horn is one of the oldest works from Africa to depict a European as a foreigner whilst simultaneously being a prestigious object authentically used in a local African context. It can most probably be dated to the period of Sapi-Portuguese trade, i.e. between the late $15^{\text {th }}$ and the mid- $16^{\text {th }}$ century. Unfortunately, the extensive Dresden inventories do not indicate how and why the change of ownership took place. The Sapi signal horn testifies to very early cultural exchange between Europe and Africa and, above all, it is a hybrid cultural item par excellence. The Other has been prominently incorporated into a hierarchically 


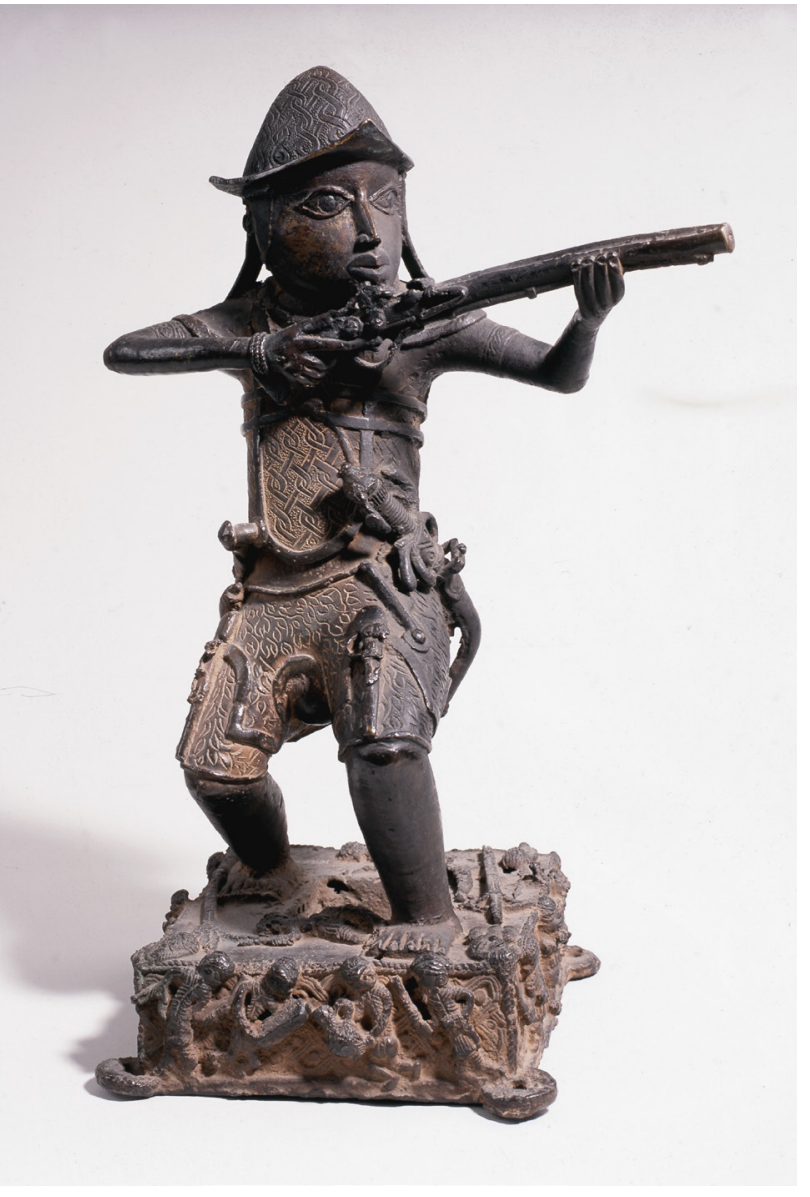

9. Portuguese Soldier, Brass, Benin Empire, Nigeria, $16^{\text {th }}-17^{\text {th }}$ cent., H. 38.5 cm, W. 38.5 cm, Museum für Völkerkunde Dresden, 1903, Inv. no. 16604. Photo: Eva Winkler

divided social structure, making an ambiguous statement, and through its stylistic execution, with allusions to formally venerated high-ranking African dignitaries, it is associated with ancestor worship and the system of belief. The Other has thus been turned into the Own and has merged with the prevailing sociocultural and religious ideas. Its purpose was not simply to underline the exclusive position of the chief and to serve as a metaphor for his unlimited authority over people and things; it also transcended into a symbol of a new status and identity granted to the local African ruler by otherworldly powers at the start of sustained cultural contact with Europe.

The arrival of white foreigners had not only a longterm but also a very profound effect on the lives of African societies. A series of works of art in wood, ivory and par- ticularly brass from the Benin Empire (in the south of what is now Nigeria), which are held in the Dresden ethnographical collection, are evidence of that process. Especially the bronze plaques in low or high relief, which were displayed in the manner of a gallery in the interior of the royal complex, bear depictions of Portuguese traders and soldiers with their typical dress and equipment, often shown in great detail. In particular, the weapons of the Portuguese, featuring muskets and guns, along with their most important means of exchange in the form of brass and copper rings (manillas) were of great interest to the African rulers. The foreigners with their modern weaponry gave the rulers of Benin decisive power-political advantages compared with their rivals within their own Empire and in the region, and the import of this metal, which was rare in Africa and highly desirable, enabled a rich tradition of court art to flourish ${ }^{17}$. Brass relief plaques and sculptures were produced for the Royal court over a long period, probably from the $13^{\text {th }}$ until the $19^{\text {th }}$ century (Egharevba, 1968: 11). With the arrival of foreigners from Europe in about 1485/86, a decisive innovation appeared in sculptural art, in which the Other was distinguished from the Own in Benin. Representations of African dignitaries display a rigid and upright posture, whereas the Portuguese figures are associated with dynamism and movement, as is evident on the aforementioned bronze plaque known under the title "King with Retinue» and in the figure of the Portuguese man (see [5] and [9]). The Other was extremely ambivalent, being both desirable and a source of fear. Over a long period, exclusive contact with the foreign people from Europe meant technological superiority and the accumulation of wealth for the ruler of Benin. This promoted his authority and power, and ultimately also his prestige in society. Through their non-negotiable firearms, however, these foreigners remained dangerous and powerful beings, who were also long regarded as emissaries of an unknown transcendental world on account of their different skin colour, their appearance and their unfamiliar possessions, particularly their deep-sea ships. The fact that they came from the sea intensified the idea that they might be associated with the most powerful deity of the Empire, the sea-god Olokun ${ }^{18}$. In this connection, owing to their impressive differentness and their dangerous character, images representing Europeans and their attributes became metaphors of magical power and transcendental forces, which the African rulers employed in order to 
10. Colon figures White officer with black soldier, clay, oil paints, early $20^{\text {th }}$ cent, Abomey, Dahomé (now Republic of Bénin), H 33.7 and 45 $\mathrm{cm}$, Staatliche Kunstsammlungen Dresden, Museum für Völkerkunde Dresden, Inv. no. 36297, 36299. Photo: Eva Winkler

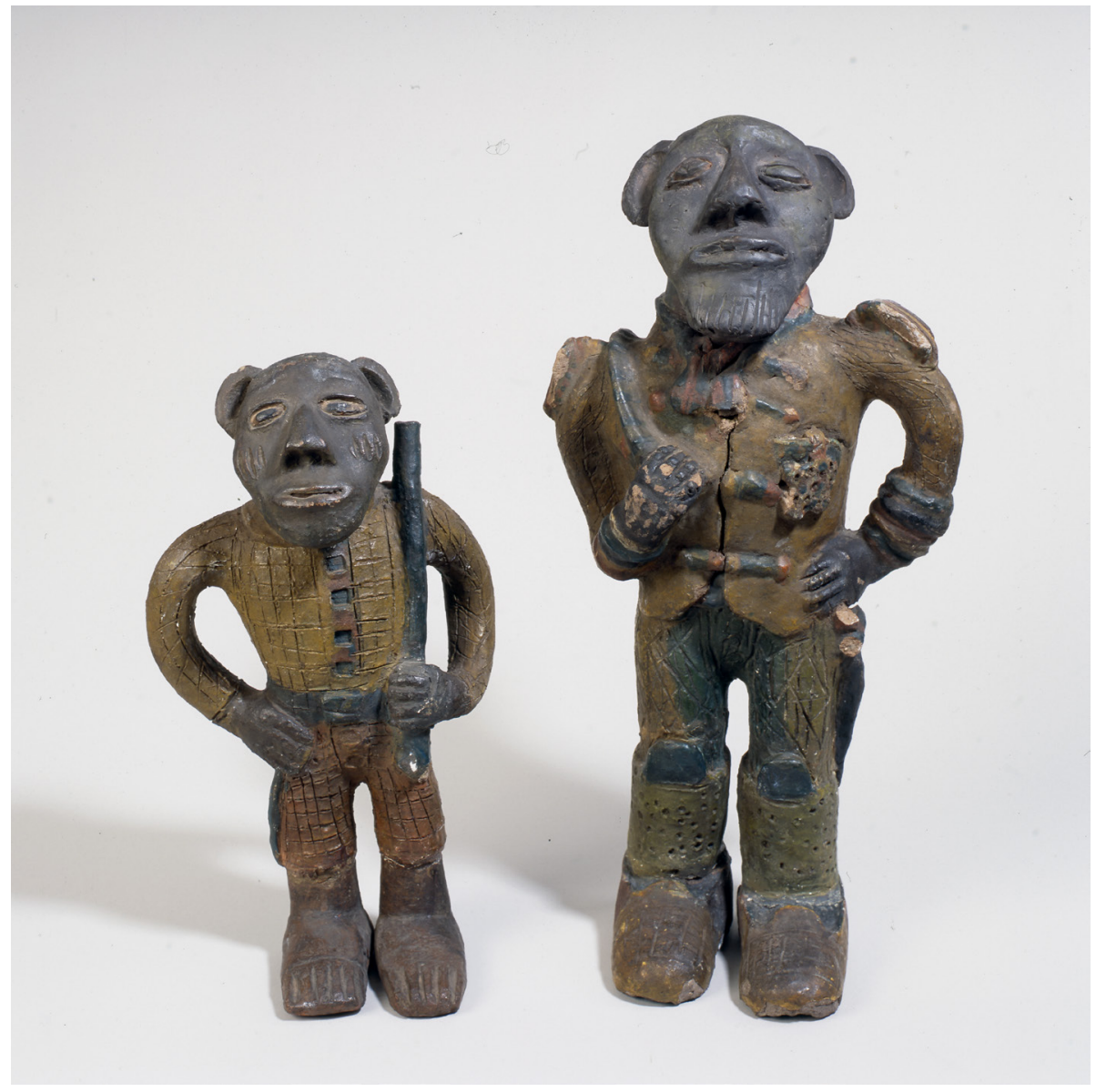

ward off danger and guarantee protection and security for themselves and their subjects in the Empire. The works of art from the historic Benin Empire incorporating representations of Portuguese people can be described as doubly ambiguous. For one thing, they absorb the Other in positive perceptions. Secondly, these objects reflect interaction between the different spheres. Thus, they are objects relating to an alien earthly world but also to an alien transcendental world. They impressively demonstrate how, by means of a religious concept, the Other, and human representatives of the Other, are integrated into their worldview as mediators between the different worlds.

In many societies in Africa it was not so much the white skin colour that typified the Other, but rather a number of different aspects. Symbolic attributes in the representation of foreign people were certain characteristics of their physiognomy (a long, narrow nose, thin lips, straight hair, a beard), their clothing (headgear, shoes, boots, a suit, tie or bow-tie) and their technical equipment (firearms, carpentered furniture, means of transport such as bicycles, cars and aircraft, as well as clocks or watches). A group of objects that has been known since the $19^{\text {th }}$ century but to which Europeans initially paid little attention are the so-called "Colon" sculptures - figures or masks depicting foreign people as soldiers and officers in uniform [10], sometimes carrying weapons, or as Christian priests or colonial officials. Despite the immediately visible foreign characteristics, all these representations are subject to the rules of the local African iconography. These sculptures - often made of wood coloured using industrially manufactured paints, or made of clay, metal or even ivory - are occasionally intended as ironic and witty depictions of Europeans. Hardly any other artistic product from Africa expresses such ambivalence and ambiguity as the Colon sculptures. Their meaning-laden foreign attributes 
are, in many cases, also used in representations of black people, i.e. the Other is combined with the Own. As such, these representations stand for modernity, prosperity, social prestige or dignity. In this way, an alter ego concentrates desires and longings, but also a transformative identity. Like the images representing Portuguese people in the Benin Empire, the Colon figures were codified and condensed means of expression enabling them to function in different ways. Produced from the end of the $19^{\text {th }}$ century, many of them represent the period of colonial domination and brutal oppression, a period when African social structures and value systems were destroyed, radically disrupting their belief systems and perceptions of the world. The Colon figures are indicators of these changed power relationships. Through the integration of the Other, with its attributes of power, into their own systems of thought and belief, they sought to appropriate the foreign power and harness it for their own benefit. The paradox was that the Colon figures were intended to constitute a powerful opposing force that would neutralise the evil brought by the foreigners. Sculptures in the form of armed (white or black) soldiers or police officers thus became protective guardian figures. By means of a psychological trick and an inversion of power, the people faced up to the menacing foreign influence and conflicts, so that the creation of these figures constituted a coping strategy.

The change of perspective outlined here is intended to contribute to the decoding of cultural artefacts, such as mu- seum objects incorporating references to the foreign or Other, or constituting hybrid phenomena, taking into account their complex character, in order to reveal the intentions of the respective cultural interaction. The objects discussed, which are associated with different geographical areas and different periods, reveal both intra-cultural and intercultural distance (Osterhammel, 1989: 10), which is perceived as foreignness and Otherness. However, the boundary between the Own and the Other in foreign people and objects is not an objective dividing line but a «...line of connection, expressing the relationship between the Own and the Other...» (Reuter, 2002: 188). The necessary defining of the Self will probably always require the existence of the Other. However, it is only by recognising the Self in its changeability and its aspects of "Otherness", and by becoming aware of one's own intentions and hegemonic structures, that it is also possible to recognise and appreciate the «foreign" that has come to be regarded as the «Other», which is likewise always in search of confirmation of its identity on the basis of its own history and experience. Thus, old and new objects in museum collections which appear «foreign" are understood as images of the Other, not so much in the sense of separating, but rather as connecting, cultural artefacts which have ambivalent and ambiguous meanings. In response to the question raised in the introduction concerning the relationships between, and the meaning of, the Own and the Other, its message may perhaps be: From the Foreign in the Familiar to the Other for the Own.

\section{Notes}

1 These include 12 Bini-Portuguese ivory spoons, three more being added later, as well as Sapi-Portuguese olifants and one salt cellar. Kunstkammer inventories 1595, 1684, 1783; (Bassani, 2000: 101-107; Dolz, 2005:94-100; Dolz in: Kolb, Lupfer, Roth (eds.), 2010: 66-70).

2 Such a figural automaton with a musical mechanism and clock, produced c.1625 in Augsburg, features two moving groups of dancers, one with white figures and one with 5 exotically dressed black figures, described as a «Hottentot dance»; part of the collection of the Mathematisch-Physikalischer Salon in Dresden since 1687 (Plaßmeyer, 2009: 170).

3 (Schnitzer, 2006: 86-99). The earliest Dresden images of actors dressed up as Moors are in depictions in opaque paint dating from 1607; the ones produced during the reign of August the Strong were painted by Johann Mock in 1706 (Von Bloh, 2006: 76-77).

4 Nickel, 1981: 14-17 with reference to Theodore de Bry, Historia Americae 1591 (India Occidentalis 1590-1634, Vol. II).

5 De Bry, 1597, Vol. 1, Plate 4, 1598, Plate 16 (reprinted 1979/1980, Vols. 1/2); Dapper 1671 (1967), Figs. pp. 513,559 and 618 «Dracht en Wapening der Hottentots»; Kolb 1719, Plates relating to pp. 411, 474, 515. The term «Hottentots» was used to refer jointly to several population groups in the south-west of South Africa - later called Khoikhoi - who became well known on account of their distinctive languages employing click consonants. The unusual sounds, which European ears perceived as «stuttering", led to the coining of this term

6 See illustrations in Syndram, 1999: pp. 65, 80, 112, 114, 149, 167 and 2004, pp. 79, 88, 89, 90, 96, 112, 125

7 De Bry, 1597, Vol 1., Plate 10, Fig. 28: p. 25

8 On this subject, see also Ketelsen, 2006: pp. 60-64.

9 Heuser, 1995: 49-52; Thode-Arora, 1989; Küster, 2006: 95-118.

10 Dalbajewa, 2001: 314-319; Karge, 2005: 14-17. 
11 Ketterer, 1988: 59. The Königliches Zoologisches und Ethnographisch-Anthropologisches Museum Dresden was founded in 1875 as one of the first ethnographic museums in Germany.

12 Ketterer, 1988: 59; Kirchner, 1925/26: pp. 333; Strzoda, 2006.

13 Lucius Grisebach, 2008: 16. Lucius Grisebach refers in this connection to Lothar Grisebach, Ernst Ludwig Kirchners Davoser Tagebuch: Eine Darstellung des Malers und seiner Schriften, Ostfildern 1997

14 The earliest clearly identifiable reference discovered so far is to be found in the 1684 inventory of the Indianische Cammer, no. 115 . Since this partial inventory was drawn up at the time when the old Kunstkammer was starting to be restructured, the possibility cannot be ruled out that the object was already in Dresden before that, particularly because no date of entry was noted nor any individual mentioned as having supplied it.

15 Phillips, 1996: 468-470; Bassani, 2005: 161-166.

16 The term «Sapi-Portuguese» is used for ivory works from the western part of the Guinea coast, between modern-day Guinea and Liberia (15 ${ }^{\text {th }}-16^{\text {th }}$ cent.), whereas the iconographically and stylistically different «Bini-Portuguese» works $\left(16^{\text {th }}-17^{\text {th }}\right.$ cent.) come from the eastern part of the Guinea coast (Nigeria). Bassani, 2005: pp. 259-281; Dolz, 2005: pp. 94-104.

17 Egharevba, 1968: pp. 26-29; Fagg, 1978: pp. 37-39; Dolz, 2007: pp. 450-452.

18 Ben Amos, 1980: 28-29; Eisenhofer, 2006: 55 with reference to Blackmun 1984.

\section{Bibliography}

DE BRY, Johann Theodor and Israel, India Orientalis (1597-1618 in 12 volumes) and India Occidentalis (1590-1630 in 14 volumes), Frankfurt am Main, here reprint: DE BRY (1979), India orientalis I/II, Kiepenheuer Verlag Leipzig, Weimar, I, Plates 4, 16, see also 1980, Plates 27,39 .

BASSANI, Ezio (2000), African Art and Artefacts in European collections 1400-1800, The Trustees of The British Museum, London. - (2005), «Ancient Ivories», in Arts of Africa. 7000 years of African Art, Exhibition Catalogue Grimaldi Forum Monaco, Monaco.

BEN AMOS, Paula (1980), The Art of Benin, Thames and Hudson, London.

BLACKMUN, Barbara (1984), The iconography of carved altar tusks from Benin, Nigeria, 3 Vol., University of California, Los Angeles.

BLOH, Jutta Charlotte von (2006), «Faszination des Fremden: Afrika-Inszenierungen am kurfürstlichen Hof in Dresden im 16. und 17. Jahrhundert», in VOLKER-SAAD, Kerstin und GREVE, Anna (ed.), Äthiopien und Deutschland. Sehnsucht nach der Ferne, Deutscher Kunstverlag München, Berlin, pp. 76-84.

DALBAJEWA, Birgit (2001), «Erwünschte Opposition. Die BRÜCKE im Spiegel der zeitgenössischen Kritik 1905-1911», in DALBAJEWA, Birgit und BISCHOFF, Ulrich (ed.), Die BRÜCKE in Dresden 1905-1911, Köln.

DAPPER, Olfert (1967), Umbständliche und eigentliche Beschreibung von Afrika, Amsterdam 1671, here Johnson Reprint Corporation, New York, Meisenheim (West Germany).

DOLZ, Silvia (2005), «Early African objects in the Electoral and Royal Collections Dresden», Anales del Museo Nacional de Antropología, XI, Madrid, pp. 89-120.

- (2007), «Portugiesen», in PLANKENSTEINER, B. (ed.), Benin Kings and Rituals. Court Arts from Nigeria, Exhibition Catalogue, Snoeck Publishers, Vienna, pp. 450-452.

- (2010), «Zierlöffel, Blashorn, Prunkschwert, Prunkbeil, Fünf Prunklanzen», in KOLB, Karin, LUPFER, Gilbert, ROTH, Martin (ed.), Zukunft seit 1560. Von der Kunstkammer zu den Staatlichen Kunstsammlungen. Die Ausstellung, Berlin, München, pp. 66-70.

EGHAREVBA, Jacob U. (1968), A Short History of Benin, Ibadan.

EISENHOFER, Stefan (2007), «Die Boten Olokuns. Die Portugiesen und das Reich Benin», in PLANKENSTEINER, B. (ed.), Benin Kings and Rituals. Court Arts from Nigeria, Exhibition Catalogue, Snoeck Publishers, Vienna, pp. 55-63.

FAGG, William B. (1978), Divine Kingship in Africa. The Museum of Mankind, London.

GREVE, Anna (2006), «Das europäische Verlangen nach Exotik: Die afrikanischen Krieger im Grünen Gewölbe», in Dresdner Kunstblätter, 2/2006, pp. 81-86.

- (2006), «Weiß-Schwarz-Malerei. Whiteness studies in der Kunstgeschichte - Suche nach einer neuen Perspektive», in VOLKER-SAAD, Kerstin und GREVE, Anna (ed.), Äthiopien und Deutschland. Sehnsucht nach der Ferne, Deutscher Kunstverlag München, Berlin, pp. 18-25.

GRISEBACH, Lucius (2008), Ernst Ludwig Kirchner und die Kunst Kameruns, Museum Rietberg Zürich, Zürich. 
GROSCHWITZ, Helmut (2017), «Das Museum als Strategie der kulturellen Ambiguitätsbewältigung», in HAHN, Hans Peter (ed.), Ethnologie und Weltkulturenmuseum. Positionen für eine offene Weltsicht, Berlin, pp. 139-172.

HEUSER, Judith (1995), «Faszination des Exotischen. Die Begegnung der Brücke-Künstler mit der ethnographischen Kultur», in BILLIG, Volkmar, Künstler der Brücke in Moritzburg. Malerei, Zeichnung, Graphik, Plastik von Heckel, Kirchner, Pechstein, Bleyl, Museum Schloss Moritzburg, pp. 49-56.

KARGE, Henrik (2005), «Der emphatische Lebensbegriff im Kunstverständnis der BRÜCKE. Zum Wechselverhältnis von Vitalismus, Boheme und Jugendkultur am Anfang des 20. Jahrhunderts», in 100 Jahre BRÜCKE - Neueste Forschung, Jahrbuch der Staatlichen Kunstsammlungen Dresden, Vol. 32, Dresden, pp. 13-19.

KETELSEN, Thomas (2006), "Äthiopien: Fragmente des Fremden», in VOLKER-SAAD, Kerstin und GREVE, Anna (ed.), Äthiopien und Deutschland. Sehnsucht nach der Ferne, Deutscher Kunstverlag München, Berlin, pp. 58-75.

KETTERER, Roman Norbert (1988), Dialoge. Bildende Kunst - Kunsthandel, Stuttgart, Zürich.

KIRCHNER, Ernst Ludwig (1979), «Die Arbeit Ernst Ludwig Kirchners, 1926», in KORNFELD, Eberhard W. T, Ernst Ludwig Kirchner. Nachzeichnung seines Lebens, Katalog der Sammlung von Werken von Ernst Ludwig Kirchner im Kirchner-Haus Davos, Bern 1979 , pp. 331-345.

KOLB (Kolben), Peter (1719), Caput bonae spei hodiernum. Das ist: Vollständige Beschreibung des Vorgebürges der Guten Hofnung, Nürnberg.

NICKEL, H. (1981), «Über die graphischen Vorlagen des «Mohren mit der Smaragdstufe» im Grünen Gewölbe zu Dresden», in Dresdener Kunstblätter 1, pp. 10-19.

OSTERHAMMEL, Jürgen (1989), «Distanzerfahrung. Darstellungsweisen des Fremden im 18. Jahrhundert», in HANS-JOACHIM KÖNIG and others (ed.), Der europäische Beobachter außereuropäischer Kulturen, Zeitschrift für Historische Forschung Beiheft 7, Berlin, pp. 9-42.

PHILLIPS, Tom (ed.) (1996), Afrika. Die Kunst eines Kontinentes, Exhibition Catalogue Martin-Gropius-Bau, Berlin.

PLANKENSTEINER, Barbara (ed.) (2007), Benin Kings and Rituals. Court Arts from Nigeria, Exhibition Catalogue, Snoeck Publishers, Vienna. PLASSMEYER, Peter (2009), «Figurenauatomat mit Musikspielwerk "Hottentottentanz"», in EMMENDÖRFFER, Christoph und PLASSMEYWE, Peter (ed.), Weltenglanz, der Mathematisch-Physikalische Salon Dresden zu Gast im Maximilianmuseum Augsburg, Deutscher Kunstverlag Berlin München.

REUTER, Julia (2002), Ordnungen des Anderen: Zum Problem des Eigenen in der Soziologie des Fremden, Bielefeld.

SCHNITZER, Claudia (2006), "Herrschende und dienende "Mohren" in den Festen Augusts des Starken», in VOLKER-SAAD, Kerstin und GREVE, Anna (ed.), Äthiopien und Deutschland. Sehnsucht nach der Ferne, Deutscher Kunstverlag München, Berlin, pp. 86-101.

STRZODA, Hanna (2006), Die Ateliers Ernst Ludwig Kirchners. Eine Studie zur Rezeption «primitiver» europäischer und außereuropäischer Kulturen, Petersberg.

SYNDRAM, Dirk (1999), Die Schatzkammer Augusts des Starken. Von der Pretiosensammlung zum Grünen Gewölbe, Leipzig.

- (2004), Schatzkunst der Renaissance und des Barock. Das Grüne Gewölbe zu Dresden, München, Berlin. 